\title{
Defective Lipid Metabolism in the Failing Heart
}

\author{
Benjamin Wittels and James F. Spann, Jr. \\ From the Department of Pathology, Duke University Medical Center, \\ Durham, North Carolina 27706 and the Cardiology Branch, National \\ Heart Institute, Bethesda, Maryland 20014
}

A в S T RACT The metabolism of long chain fatty acids was investigated in the failing heart of guinea pigs with chronic constriction of the ascending aorta. Homogenates prepared from failing hearts exhibited $(a)$ a decreased capacity to oxidize palmitic acid (failure $=0.50 \pm 0.06 \mu \mathrm{mole}$ / $\mathrm{g}$ of protein per $20 \mathrm{~min}$; control $=1.09 \pm 0.10$ ); (b) a reduced level of carnitine, a myocardial constituent which serves to control the oxidation rate of long chain fatty acids in the heart (failure $=0.91 \pm 0.10 \mu \mathrm{mole} / \mathrm{g}$ wet weight; control = $1.69 \pm 0.10)$; and $(c)$ an increased rate of palmitate incorporation into triglycerides and lecithin. Exogenous carnitine effected a restoration of the defective palmitate metabolism of the homogenates towards normal. In contrast to long chain fatty acid oxidation, glucose oxidation by the failing heart was not impaired. As a consequence of this selective lesion in energy substrate utilization, the failing heart might be forced to rely on substrates other than long chain fatty acids for its major energy supply.

\section{INTRODUCTION}

Long chain fatty acids constitute a major fraction of the energy-yielding substrates utilized by the heart (1-3). From studies in man and the intact dog, several investigators have concluded that in the chronically failing heart, myocardial usage of lipids for energy production is not impaired $(4,5)$. This conclusion, however, is subject to certain reservations since coronary sinus cathe-

Dr. Spann's current address is Departments of Medicine and Physiology, School of Medicine, University of California, Davis, Calif. 95616.

Received for publication 27 September 1967 and in revised form 2 April 1968. terization, the technique employed in these studies, has recognized limitations. Firstly, steady-state conditions must be assumed to prevail in measuring coronary blood flow and consequently in determining myocardial utilization of a substrate (6) ; secondly, the method provides no direct knowledge of the intermediate metabolism of the utilized substrate ( 7$)$; and finally, the quantity of a substrate catabolized to $\mathrm{CO}_{2}$ and $\mathrm{H}_{2} \mathrm{O}$ is inferred from an oxygen extraction ratio (1). In view of these limitations, the metabolism of lipids in the failing heart appeared to require a more direct evaluation.

The metabolism of long chain fatty acids by cardiac muscle from the failing heart was studied in myocardial homogenates from guinea pigs with chronic constriction of the ascending aorta. The data obtained provide evidence of a marked depression in the capacity of the failing heart to oxidize long chain fatty acids. In addition, the concentration of carnitine, a myocardial constituent that controls the rate of long chain fatty acid oxidation in the heart $(8,9)$, was markedly reduced. Significantly, and in accord with recent studies on the failing heart in man and the experimental animal, no indication of impaired mitochondrial oxidative function was observed as a basis for the defect in lipid metabolism (10-12).

\section{METHODS}

Heart failure was produced, with an established technique, in adult male guinea pigs weighing from 650 to $900 \mathrm{~g}$ by marked constriction of the ascending aorta $(13,14)$. 2-mm clips were used for the constriction. Sham-operated animals were prepared by the same method except that the constricting aortic clip was removed immediately after application. A standard diet consisting of $50 \%$ Purina rabbit chow and $50 \%$ oats supplemented with fresh cabbage was offered to all operated animals and their con- 
trols. Body weights were recorded daily for at least 1 wk before the metabolic studies. Except for the immediate postoperative period, the operated animals gained body weight at a rate comparable to that shown by the controls.

16-39 days postoperatively, the treated animals and their controls were killed by a blow on the head. The pleural spaces were exposed to determine the presence of hydrothorax. The degree of reduction of the aortic lumen by the constricting clip was measured. The left ventricle together with the ventricular septum was freed from the great vessels, atria and right ventricle, blotted on filter paper, and weighed.

Left ventricles used to assess the effect of aortic constriction on myocardial protein, ribonucleic acid (RNA), and deoxyribonucleic acid (DNA) concentrations were homogenized in $30 \mathrm{ml}$ of calcium-free Krebs-Ringer phosphate buffer, $\mathrm{pH}$ 7.4. Protein concentration was measured by the biuret method (15), RNA by the orcinol method of Ceriotti (16), and DNA by the $p$-nitrophenylhydrazine method of Webb and Levy (17).

The capacity of left ventricular homogenates to oxidize selected substrates was assessed by collection of ${ }^{14} \mathrm{CO}_{2}$ from ${ }^{14} \mathrm{C}$-labeled substrate as previously described (18). Each constricted and sham animal used for an enzymatic assay was tested simultaneously with an untreated mate as a control. The homogenates were prepared so that the wet tissue weight per volume of homogenizing medium was approximately equal for the operated and control specimens. The specific activities of the palmitate and glucose in the reaction mixtures were estimated as follows: the concentration of free fatty acid in the myocardium was determined by the method of Amenta (19) and that of glucose by the procedure of Washico and Rice (20). The myocardium from the failure animals contained $1.53 \pm 0.11 \mu$ moles (mean $\pm \mathrm{SE}$ ) of free fatty acids per $\mathrm{g}$ wet weight, and from the controls, 2.25 \pm 0.54 . The values for glucose were $0.65 \pm 0.15 \mu \mathrm{mole} / \mathrm{g}$ wet weight and $0.83 \pm 0.20$, respectively. Since identical amounts of radioactive fatty acid or of glucose were added to the reaction mixtures, the specific activities of the respective substrates in the reaction mixtures at the beginning of the incubation period were considered equal. To determine whether or not the specific activity changed during the incubation period, time course experiments were done over an interval of 5-30 min. During incubation, the reaction rates were linear, and a fixed ratio of ${ }^{14} \mathrm{CO}_{2}$ evolved was maintained between the two groups. This was considered to indicate that significant net lipolysis or glycogenolysis with dilution of the free fatty acid or glucose pools did not occur during the $20 \mathrm{~min}$ incubation period used in these experiments.

After the ${ }^{14} \mathrm{CO}_{2}$ produced in the palmitate assay had been collected, the lipids in the reaction mixture were extracted as previously described (21). The dried lipid extracts were dissolved in $1 \mathrm{ml}$ of benzene. Glycerides, phospholipids, and palmityl carnitine were separated from the extracted lipids by thin-layer silica gel chromatography. A solvent system consisting of $n$-hexane: diethyl ether: glacial acetic acid $(85: 15: 1)$ was used to separate triglycerides; phospholipids and palmityl carnitine were separated by a two-dimensional system as described previously (22). The chromatograms were stained by exposure to iodine vapor, and the areas corresponding to the desired lipid fractions were encircled. After the iodinestained spots had completely faded, the plates were sprayed with Neatan, (Brinkman Instruments, Westbury, N. Y.), and the encircled areas of silica gel were transferred to vials for scintillation counting. $12 \mathrm{ml}$ of toluene containing 2,5-diphenyloxazole ( $\mathrm{PPO}, 4 \mathrm{~g} /$ liter), 1,4 bis[2-(5-phenyloxazolyl)]benzene (POPOP, $100 \mathrm{mg} /$ liter), and $4 \%$ Cab-O-Sil thixotropic gel powder, Cabot Corporation, Boston, Mass., were used as the phosphor solution. Correction for quenching was carried out by the channel ratio method according to Bruno and Christian (23).

Activity of the long chain fatty acid activating enzyme was assayed by the method of Kornberg and Pricer (24) and the activity of the long chain fatty acyl coenzyme A (CoA) carnitine transferase by the method of Fritz and Yue (25). For these determinations, homogenates were prepared in $0.37 \mathrm{~m}$ sucrose and centrifuged at $2,000 \mathrm{rpm}$ at $2-4^{\circ} \mathrm{C}$ for $10 \mathrm{~min}$. Aliquots of the resulting supernatants were used.

Myocardial free and bound carnitine was extracted by the method of Pearson and Tubbs (26). Carnitine concentration was determined enzymatically by the method of Marquis and Fritz (27). The short chain fatty acyl CoA carnitine transferase used in the carnitine assay was prepared from pigeon breast muscle by the procedure of Chase, Pearson, and Tubbs (28).

Radioactive substrates: carboxyl-labeled palmitic acid, succinate-2,3- ${ }^{14} \mathrm{C},{ }^{1}$ and glucose- $\mathrm{U}-{ }^{14} \mathrm{C}{ }^{2}$ were obtained commercially. L-Palmityl carnitine was prepared by the method of Brendel and Bressler (29), palmityl CoA by the method of Goldman and Vagelos (30), and acetyl CoA by the method of Stadtman (31). Nonradioactive palmitic acid, ${ }^{3}$ (-)-carnitine, ${ }^{4}$ coenzyme $A, 5$ adenosine triphosphate (ATP), ${ }^{6}$ RNA, and $\mathrm{DNA}^{7}$ were purchased. As determined by gas liquid chromatography, the radioactive palmitate was $95 \%$ chemically pure and $98 \%$ radio pure.

The statistical significance of the data was evaluated by applying the $t$ test to the mean differences between operated and control pairs or operated and control groups (32).

\section{RESULTS}

Heart failure and left ventricular hypertrophy. In the group of 14 guinea pigs with aortic constriction, the lumen of the ascending aorta was

${ }^{1}$ International Chemical and Nuclear Corp., City of Industry, Calif.

2 New England Nuclear Corp., Boston, Mass.

3 Applied Science Laboratories, Pennsylvania State, Pa.

4 General Biochemicals, Chagrin Falls, Ohio.

5 Calbiochem., Los Angeles, Calif.

${ }^{6}$ Sigma Chemical Co., St. Louis, Mo.

7 Washington Biochemical Corp., Freehold, N. J. 
reduced to $5-15 \%$ of normal at the constricted site. Cardiac failure was manifested in each animal with aortic constriction by hydrothorax. The left ventricle was grossly hypertrophied in these animals as evidenced by wet weight, concentrations of protein, RNA and DNA, and the RNA: DNA ratio (Table I).

None of three sham-operated animals or any of the 17 control guinea pigs had hydrothorax. The left ventricular weight in the sham-operated animals was not significantly different from the controls $($ sham $=1.59 \pm 0.05$ [mean $\pm \mathrm{SEM}] \mathrm{g} / \mathrm{kg}$ of body weight; control $=1.57 \pm 0.05$ ).

Long chain fatty acid oxidation. The rate of palmitate- $1-{ }^{14} \mathrm{C}$ oxidation by homogenates prepared from the left ventricle of failure animals was reduced to less than one half of that shown by paired controls (Table II, columns 1 and 2). The palmitate oxidation rate in the left ventricular homogenate from the three sham-operated guinea pigs was not significantly different from their

TABLE I

Left Ventricular ( $L V)$ Weight, Concentrations of Protein, $R N A$ and DNA, and RNA/DNA Ratio in Guinea Pigs with Failure

\begin{tabular}{|c|c|c|}
\hline & Control & Failure \\
\hline \multicolumn{3}{|c|}{ LV wet weight, $g / k g$ body weight } \\
\hline Mean $(14)^{*}$ & 1.64 & 2.44 \\
\hline $\mathrm{SE}$ & 0.04 & 0.09 \\
\hline$P$ & & \\
\hline \multicolumn{3}{|c|}{ LV protein, $m g / g$ wet weight } \\
\hline Mean (3) & 234 & 213 \\
\hline $\mathrm{SE}$ & 28 & 16 \\
\hline$P$ & \multicolumn{2}{|c|}{$<0.30>0.20$} \\
\hline \multicolumn{3}{|c|}{ RNA, $\mu g / m g$ protein } \\
\hline Mean (3) & 3.10 & 3.37 \\
\hline $\mathrm{SE}$ & 0.45 & 0.17 \\
\hline$P$ & \multicolumn{2}{|c|}{$<0.40>0.30$} \\
\hline \multicolumn{3}{|c|}{ DNA, $\mu g / m g$ protein } \\
\hline Mean (3) & 1.97 & 1.01 \\
\hline $\mathrm{SE}$ & 0.43 & 0.14 \\
\hline$P$ & \multicolumn{2}{|c|}{$<0.05>0.025$} \\
\hline \multicolumn{3}{|l|}{ RNA/DNA } \\
\hline Mean (3) & 1.61 & 2.92 \\
\hline $\mathrm{SE}$ & 0.08 & 0.11 \\
\hline$P$ & \multicolumn{2}{|c|}{$<0.025>0.01$} \\
\hline
\end{tabular}

* Number of animals in each of the control and failure groups. controls (sham $=1.08 \pm 0.16 \mu$ moles $/ \mathrm{g}$ of protein per $20 \mathrm{~min}$; control $=0.96 \pm 0.08$ ).

To delineate the basis of the depressed rate of palmitate oxidation in the failure animals, successive steps in the long chain fatty acid oxidation pathway were examined. Activity of the ATP long chain fatty acylthiokinase in the left ventricle of four failure animals was not significantly different from paired controls (failure $=$ $0.071 \pm 0.029 \mu$ mole of palmityl hydroxamate per $\mathrm{mg}$ of protein per $30 \mathrm{~min}$; control $=0.086 \pm$ $0.010)$. Addition of ATP in final concentrations of $10^{-2}-10^{-4} \mathrm{~mole} /$ liter or of $\mathrm{CoASH}$ in concentrations of $10^{-5}-10^{-4} \mathrm{~mole} / \mathrm{liter}$ failed to increase the palmitate oxidation rate.

Recently, the participation of a carnitine-palmityltransferase system has been implicated in the oxidation of activated palmitate groups by the heart $(8,25)$. Accordingly, by means of the transesterification reaction:

$$
\text { palmityl CoA }+(-) \text {-carnitine }
$$

carnitine-palmityltransferase $\rightleftharpoons$

$$
\text { (-)-palmityl carnitine }+\mathrm{CoA}
$$

activated palmitate groups are transported across a mitochondrial barrier which separates the sites of palmitate activation from intramitochondrial sites of oxidation. In comparing four animals in failure with paired controls, a significant difference in the activity of carnitine-palmityltransferase was not demonstrable (failure $=0.017 \pm$ $0.004 \mu$ mole of palmitylhydroxamate per $\mathrm{mg}$ of protein per $15 \mathrm{~min}$; control $=0.017 \pm 0.002$ ). On the other hand, the concentrations of free and total carnitine in the left ventricle of a group of six failure animals were reduced to approximately $50 \%$ of control values (Table III). The consequence of the reduced carnitine levels on the rate of palmitate-1 ${ }^{14} \mathrm{C}$ oxidation shown by the hearts of the failure animals is evidenced by the decreased rate of palmityl carnitine $-{ }^{14} \mathrm{C}$ formation by these preparations (Table IV).

The addition of $(-)$-carnitine to the reaction mixtures doubled the rate of palmitate- $1-{ }^{14} \mathrm{C}$ oxidation by the myocardium of the failure animals (Table II, columns 2 and 4). Although the increment effected by the exogenous carnitine increased the rate of palmitate oxidation in the failure animals to the control levels (Table II, columns 1 and 4 ) the rate attained was only two-thirds of 
TABLE II

Palmitate-1-14C Oxidation by the Left Ventricle of Animals with Failure in the Presence and Absence of ( - )-Carnitine*

\begin{tabular}{|c|c|c|c|c|c|c|c|c|c|}
\hline \multirow[b]{4}{*}{ Expt. No. } & \multicolumn{9}{|c|}{${ }^{14} \mathrm{CO}_{2}$} \\
\hline & \multirow[t]{2}{*}{ Control } & \multirow[t]{2}{*}{ Failure } & Control & \multirow{2}{*}{$\begin{array}{l}\text { Failure } \\
\text { ne }\end{array}$} & \multicolumn{5}{|c|}{ Difference } \\
\hline & & & Carnitine & & \multirow[b]{2}{*}{$1-2$} & \multirow[b]{2}{*}{$3-1$} & \multirow[b]{2}{*}{ 4-2 } & \multirow[b]{2}{*}{$3-4$} & \multirow[b]{2}{*}{ 4-1 } \\
\hline & 1 & 2 & 3 & 4 & & & & & \\
\hline & \multicolumn{9}{|c|}{$\mu$ moles $/ \mathrm{g}$ of protein per $20 \mathrm{~min}$} \\
\hline 1 & 0.97 & 0.38 & 1.40 & 0.63 & 0.59 & 0.43 & 0.25 & 0.77 & -0.34 \\
\hline 2 & 1.28 & 0.63 & 1.96 & 1.14 & 0.65 & 0.68 & 0.51 & 0.82 & -0.14 \\
\hline 3 & 0.76 & 0.39 & 1.02 & 0.89 & 0.37 & 0.26 & 0.50 & 0.13 & 0.13 \\
\hline 4 & 1.16 & 0.34 & 1.50 & 0.75 & 0.82 & 0.34 & 0.41 & 0.75 & -0.41 \\
\hline 5 & 1.49 & 0.71 & 2.10 & 1.39 & 0.78 & 0.61 & 0.68 & 0.71 & -0.10 \\
\hline 6 & 1.12 & 0.71 & 1.85 & 1.30 & 0.41 & 0.73 & 0.59 & 0.55 & 0.18 \\
\hline 7 & 0.84 & 0.34 & 1.35 & 0.86 & 0.50 & 0.51 & 0.52 & 0.49 & 0.02 \\
\hline Mean & 1.09 & 0.50 & 1.60 & 1.00 & 0.59 & 0.51 & 0.49 & 0.60 & 0.09 \\
\hline $\mathbf{S E}$ & 0.10 & 0.06 & 0.14 & 0.11 & 0.07 & 0.07 & 0.05 & 0.09 & 0.08 \\
\hline$P$ & & & & & $<0.01$ & $<0.01$ & $<0.01$ & $<0.01$ & $<0.20>0.10$ \\
\hline
\end{tabular}

* Each reaction flask contained palmitate-1-14 $\mathrm{C}, 100 \mathrm{~m} \mu$ moles $(120,000 \mathrm{cpm})$ and $10-16 \mathrm{mg}$ of guinea pig heart homogenate protein in $1 \mathrm{ml}$ of calcium-free Krebs-Ringer phosphate buffer, $\mathrm{pH} \mathrm{7.4.} \mathrm{(-)-Carnitine,} 1 \mu$ mole, was added where indicated. Final reaction volume was $1.03 \mathrm{ml}$. Incubations were at $30^{\circ} \mathrm{C}$ for $20 \mathrm{~min}$. In each experiment a failure and control animal were studied simultaneously.

that achieved when exogenous carnitine was added to the controls (Table II, columns 3 and 4).

The structural integrity of mitochondria is compromised by palmityl CoA in the absence of albumin due to the surface-active properties of palmityl CoA (25). Incubation of the cardiac homogenates with palmityl $\mathrm{CoA}$ in the absence of albumin thereby affords a means by which activated palmitate groups can gain direct access to intramitochondrial oxidative pathways. Under these conditions, no differences between failure and control animals in the rate of palmityl CoA${ }^{14} \mathrm{C}$ oxidation was demonstrable (Table V). When, however, bovine serum albumin was added to

TABLE III

Left Ventricular Carnitine Concentration in Guinea Pigs with Heart Failure

\begin{tabular}{lccc}
\hline & \multicolumn{3}{c}{ Carnitine concentration } \\
\cline { 2 - 4 } & Free & Bound & Total \\
\hline \multicolumn{4}{c}{$\mu$ moles $/ g$ wet weight } \\
Control (6) & $1.14 \pm 0.07^{*}$ & $0.55 \pm 0.15$ & $1.69 \pm 0.10$ \\
Failure (6) & $0.57 \pm 0.05$ & $0.34 \pm 0.08$ & $0.91 \pm 0.10$ \\
$P$ & $<0.01$ & $<0.20>0.10$ & $<0.01$ \\
\hline
\end{tabular}

Number in parentheses represents the number of animals in each group.

* Mean \pm SE. the reactions to protect the mitochondria, there was a marked reduction in the oxidation rate of palmityl $\mathrm{CoA}-1-{ }^{14} \mathrm{C}$ in the failure animals (Table VI). From these observations, it is inferred that an abnormality of the $\beta$-oxidation mechanism, Krebs cycle, or electron transport system is not the basis of the depressed rate of palmitate oxidation in the failure animals. With albumin-protected mitochondria, however, a critical reduction of the myocardial carnitine concentration could limit the rate at which activated palmitate groups are trans-

TABLE IV

Incorporation of Palmitate-1 $1{ }^{14} \mathrm{C}$ into Palmityl Carnitine${ }^{14} \mathrm{C}$ in Hearts from Failure and Control Animals*

\begin{tabular}{|c|c|c|}
\hline \multirow[b]{2}{*}{ Expt. No. } & \multicolumn{2}{|c|}{ Palmityl carnitine-14 $\mathrm{C}$} \\
\hline & Control & Failure \\
\hline & \multicolumn{2}{|c|}{ $\mu$ mole $/ g$ of protein per 20 min } \\
\hline 1 & 0.213 & 0.139 \\
\hline 2 & 0.205 & 0.132 \\
\hline
\end{tabular}

${ }^{*}$ Each reaction flask contained palmitate- $1-{ }^{14} \mathrm{C}, 100$ m $\mu$ moles $(120,000 \mathrm{cpm}),(-)$-palmityl carnitine, $2 \mu$ moles, and 11-14 mg of guinea pig heart homogenate protein in $1 \mathrm{ml}$ of calcium-free Krebs-Ringer phosphate buffer, $\mathrm{pH}$ 7.4. Final reaction volume was $1.12 \mathrm{ml}$. Incubations were at $30^{\circ} \mathrm{C}$ for $20 \mathrm{~min}$. Extraction and separation of palmityl carnitine were carried out as described in the Methods section. 
TABLE V

Oxidation of Various Substrates by Left Ventricle of Failure and Control Animals*

\begin{tabular}{|c|c|c|c|}
\hline \multirow[b]{2}{*}{ Substrate } & \multirow{2}{*}{$\begin{array}{l}\text { No. of } \\
\text { experiments }\end{array}$} & \multicolumn{2}{|c|}{${ }^{14} \mathrm{CO}_{2}$} \\
\hline & & Control & Failure \\
\hline & & \multicolumn{2}{|c|}{$\mu$ moles $/ \mathrm{g}$ of protein per $20 \mathrm{~min}$} \\
\hline Palmityl CoA-1-14 C & 3 & $2.7 \pm 0.1 \ddagger$ & $2.8 \pm 0.3$ \\
\hline Glucose-U-14C & 7 & $11.0 \pm 1.1$ & $10.2 \pm 0.7$ \\
\hline Succinate-2, 3-14 C & 7 & $5.2 \pm 0.6$ & $4.3 \pm 0.7$ \\
\hline
\end{tabular}

* Each reaction flask contained $10-16 \mathrm{mg}$ of guinea pig heart homogenate protein in $1 \mathrm{ml}$ of calcium-free KrebsRinger phosphate buffer, $\mathrm{pH} 7.4$, and palmityl CoA-1-14 $\mathrm{C}$, $0.5 \mu$ mole $(330,000 \mathrm{cpm})$; glucose-U-14 C, $1.0 \mu$ mole $(840,000$ cpm); or Succinate-2, ${ }^{3-14} \mathrm{C}, 1.0 \mu$ mole $(250,000 \mathrm{cpm})$. Final reaction volume was $1.10 \mathrm{ml}$. Incubations were at $30^{\circ} \mathrm{C}$ for $20 \mathrm{~min}$.

$\ddagger$ Mean \pm standard error.

located from the extramitochondrial sites of activation to the intramitochondrial sites of oxidation and thereby results in the depressed rate of palmityl CoA oxidation observed in the failure animals.

Incorporation of palmitate $-1-{ }^{14} \mathrm{C}$ into myocardial lipids. In contrast to the rate of palmitate oxidation, the net rates of triglyceride- ${ }^{14} \mathrm{C}$ and of lecithin- ${ }^{14} \mathrm{C}$ synthesis were higher in the hearts of the failure animals than in the controls (Table VII). (-)-Carnitine decreased the rates of palmitate incorporated into these lipids in both the failure and control hearts. Only in the case of triglyceride, however, was the decrement effected by carnitine in the failure animals sufficient to decrease the rate of formation to that of the control.

Glucose and succinate oxidation. As shown in Table V, significant differences in the rates of glu-

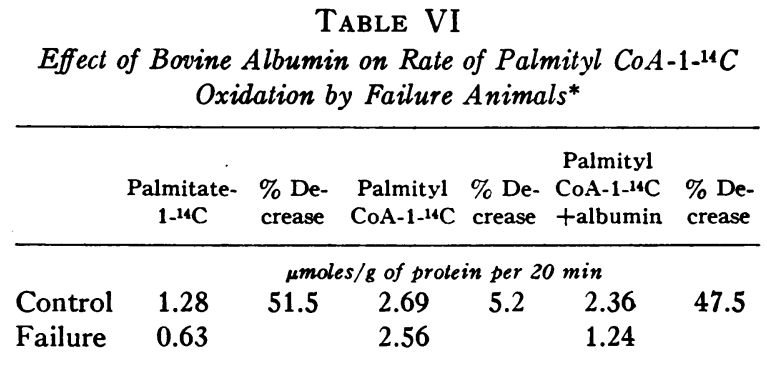

*Each reaction mixture contained palmitate-1-14 $\mathrm{C}, 100$ $\mathrm{m} \mu$ moles $(120,000 \mathrm{cpm})$, or palmityl CoA-1-14 $\mathrm{C}, 500$ $\mathrm{m} \mu$ moles $(330,000 \mathrm{cpm})$, and $14.8 \mathrm{mg}$ of failure or $12.2 \mathrm{mg}$ of control guinea pig heart homogenate in $1 \mathrm{ml}$ of calciumfree Krebs-Ringer phosphate solution. 0.1 cc of $2.5 \%$ bovine serum albumin was added as shown. Final reaction volume was $1.3 \mathrm{ml}$. Standard conditions of incubations were used. The results given are representative of three experiments.

cose or succinate oxidation were not demonstrable between the failure animals and their paired controls.

\section{DISCUSSION}

Long chain fatty acid oxidation in the failing heart of the guinea pig was characterized by $(a)$ a depressed rate of palmitate oxidation, $(b)$ a reduction in the concentration of carnitine, and $(c)$ an increased rate of palmitate incorporation into triglyceride and lecithin.

Long chain fatty acid oxidation. Decreased availability of ATP related to inefficient oxidative phosphorylation has been implicated as a metabolic basis of heart failure $(14,33-35)$. Since ATP is required to convert long chain fatty acids into activated acyl groups in preparation for their oxidation by the heart, lack of ATP could have been

TABLE VII

Incorporation of Palmitate-1-14C into Lipid Fractions of Failure and Control Hearts*

\begin{tabular}{|c|c|c|c|c|}
\hline \multirow[b]{3}{*}{ Lipid fraction } & \multicolumn{4}{|c|}{ Palmitate-1.14 C } \\
\hline & \multicolumn{2}{|c|}{ Control } & \multicolumn{2}{|c|}{ Failure } \\
\hline & \multicolumn{2}{|r|}{+ Carn } & \multicolumn{2}{|r|}{ +Carn } \\
\hline & \multicolumn{4}{|c|}{$\mu$ mole $/ \mathrm{g}$ of protein per $20 \mathrm{~min}$} \\
\hline Triglyceride & $0.073 \pm 0.011$ & $0.50 \pm 0.010$ & $0.104 \pm 0.009$ & $0.072 \pm 0.010$ \\
\hline Lecithin & $0.145 \pm 0.017$ & $0.109 \pm 0.011$ & $0.223 \pm 0.023$ & $0.183 \pm 0.017$ \\
\hline
\end{tabular}

* Each reaction flask contained palmitate-1-14 $\mathrm{C}, 100 \mathrm{~m} \mu$ moles $(120,000 \mathrm{cpm})$, and $10-16 \mathrm{mg}$ of guinea pig heart homogenate protein in $1 \mathrm{ml}$ calcium-free Krebs-Ringer phosphate buffer, $\mathrm{pH}$ 7.4. ( -)-Carnitine, $1 \mu$ mole, was added where indicated. Final reaction volume was $1.03 \mathrm{ml}$. Incubations were at $30^{\circ} \mathrm{C}$ for $20 \mathrm{~min}$. Extraction and separation of lipids were carried out as described in the Methods section. The values represent the means and standard errors of four experiments. $\ddagger(-)$-Carnitine. 
responsible for the depressed rate of palmitate oxidation in the hearts of the guinea pigs with failure. The observations, however, that supplementary ATP did not improve the rate of palmitate oxidation and that glucose phosphorylation, as indicated by oxidation, was not impeded are inconsistent with this hypothesis. Furthermore, ATP, which is necessary for a carnitine-effected stimulation of long chain fatty acid oxidation (25), was sufficiently abundant in these hearts to obtain an elevation of the depressed rate of palmitate oxidation when carnitine was added to these preparations. Thus, the evidence suggests that endogenously available ATP was not rate limiting in long chain fatty acid oxidation in these hearts. This is in accord with observations that myocardial levels of ATP are not decreased in the failing heart $(10,36)$.

The presence of defective Krebs cycle and electron transport activity has been observed in experimentally induced heart failure (37). In the current study the unimpeded oxidation of glucose and succinate and of palmityl CoA in the absence of albumin was considered to exclude abnormalities at these sites and in $\beta$-oxidation as the basis of the depressed rate of palmitate oxidation. This conclusion is consistent with recent observations that mitochondria from the failing human heart and from animals with induced failure show normal oxidative function (10-12).

The participation of carnitine in long chain fatty acid oxidation is supported by evidence from several laboratories $(25,38,39)$. Carnitine, which is almost ubiquitous in mammalian tissues, is especially abundant in muscle (40). In the heart, palmitate and palmityl CoA oxidation appear to be completely dependent on the presence of carnitine (9), the rate of oxidation being controlled by the carnitine concentration (8). According to current concepts, this regulatory function is mediated by the formation of acyl carnitine derivatives which serve to effect the transport of activated acyl groups across a mitochondrial barrier from sites of activation to those of oxidation $(25,38)$.

In the guinea pigs. with heart failure, the levels of carnitine in the left ventricle were markedly reduced. That these depressed levels of carnitine were rate limiting in palmitate oxidation in these hearts is evidenced by $(a)$ the location of the defect in the long chain fatty acid oxidation pathway, (b) the depressed rate of palmityl CoA oxidation in homogenates containing albumin and the unimpaired rate in homogenates whose mitochondria were not protected by albumin, and $(c)$ the depressed rate of palmityl carnitine $-{ }^{14} \mathrm{C}$ formation from palmitate- $1-{ }^{14} \mathrm{C}$.

Although supplementary carnitine was capable of elevating the rate of palmitate oxidation by the failing hearts to control levels, the rates achieved were not equivalent to those of the controls to which exogenous carnitine was added. This finding suggests that other factors might have limited the rate of long chain fatty acid oxidation in the failing hearts. In the isolated perfused heart, the conversion of palmitate to $\mathrm{CO}_{2}$ can be stimulated by norepinephrine (41). Since norepinephrine levels are markedly reduced in the failing heart (42-44), catecholamine depletion may also have played a role in limiting the rate of long chain fatty acid oxidation in the failing preparations.

Long chain fatty acid esterification. In contrast to its lower rate of palmitate oxidation, the failing heart showed a higher rate of palmitate incorporation into lecithin and triglyceride than the controls. Of the total amount of palmitate converted to identified end products, $39 \%$ was present as esters in the failing heart, whereas in the controls this value was 17 . It is possible that had additional myocardial lipids been investigated, an even greater percent of the total palmitate used by the failing heart would have been detected in esterified form. This quantitative redistribution of the palmitate metabolized by the failing heart suggests that although the total amount of plasma lipid taken up by the failing heart might not be different from the normal (1), the percent utilized for immediate energy production is greatly reduced.

On addition of exogenous carnitine to the reactions, the rates of palmitate esterification decreased in both the failing heart and control. Since carnitine has no direct effect on the incorporation of palmitate into glycerides, the decrease effected by carnitine is considered to be secondary to the concurrent increase in the rate of palmitate oxidation (45). This finding may indicate that the palmitate which is converted to triglyceride when the carnitine concentration is suboptimal in the failing heart is redirected to oxidation when the carnitine concentration is raised. A similar mechanism may ap- 
ply in the case of lecithin formation in the guinea pig heart, although no effect of carnitine on the rate of palmitate incorporation into lecithin has been demonstrated in either beef heart mitochondria or rat heart homogenates $(46,47)$.

Nutritional status. Even though maintenance of body weight was similar in both failure and control groups, the possibility was considered that fluid accumulation could have obscured a loss of tissue mass in the failure animals and, thus, that an altered nutritional state was responsible for the observed changes in lipid metabolism. Weight loss due to either restriction of caloric intake or increased metabolic demand, however, is associated with enhanced rather than depressed rates of long chain fatty acid oxidation by the heart $(48,49)$ and increased levels of carnitine palmityltransferase activity $(49,50)$. Thus, it appears unlikely that the defective lipid metabolism demonstrated in the failing heart resulted from an abnormal nutritional state.

Cardiac failure and hypertrophy. The possibility exists that the hypertrophic response of the heart due to aortic constriction, rather than the failure, was related to the observed defects in long chain fatty acid metabolism. Although this cannot be excluded, the hypertrophied hearts of hyperthyroid guinea pigs show increased rather than decreased rates of palmitate oxidation and levels of carnitine, increased rather than unaltered activity of carnitine palmityltransferase, and decreased rather than unimpaired rates of glucose oxidation (49). Thus, it would appear unlikely that ventricular hypertrophy per se is the basis of the abnormal lipid metabolism observed in the heart failing consequent to aortic constriction.

\section{ACKNOWLEDGMENTS}

This work was supported by U. S. Public Health Service Grants HE 10090 and American Heart Association Grant 64-G116.

\section{REFERENCES}

1. Bing, R. J., A. Siegel, I. Ungar, and M. Gilbert. 1954. Metabolism of the human heart. II. Studies on fat, ketone and amino acid metabolism. Am. J. Med. 16: 504.

2. Gordon, R. S., Jr., and A. Cherkes. 1956. Unesterified fatty acid in human blood plasma. J. Clin Invest. 35: 206.

3. Carlsten, A., B. Hallgren, R. Jagenburg, A. Svanborg, and L. Werko. 1961. Myocardial metabolism of glucose, lactic acid, amino acids and fatty acids in healthy human individuals at rest and at different work loads. Scand. J. Clin. Lab. Invest. 13: 418.

4. Blain, J. M., H. Schafer, A. L. Siegel, and R. J. Bing. 1956. Studies in myocardial metabolism. VI. Myocardial metabolism in congestive failure. $\mathrm{Am}$. J. Med. 20: 820 .

5. Olson, R. E. 1959. Myocardial metabolism in congestive heart failure. J. Chronic Diseases. 9: 442.

6. Zierler, K. L. 1961. Theory of the use of arteriovenous concentration differences for measuring metabolism in steady and non-steady states. J. Clin. Invest. 40: 2111.

7. Bing, R. J. 1965. Cardiac metabolism. Physiol. Rev. 45: 171 .

8. Fritz, I. B., and N. R. Marquis. 1965. The role of acylcarnitine esters and carnitine palmityltransferase in the transport of fatty acyl groups across mitochondrial membranes. Proc. Natl. Acad. Sci. U. S. 54: 1226.

9. Bode, C., and M. Klingenberg. 1965. Die Veratmung von Fettsäuron in isolierten Mitochondrien. Biochem. Z. $341: 271$.

10. Chidsey, C. A., E. C. Weinbach, P. E. Pool, and A. G. Morrow. 1966. Biochemical studies of energy production the failing human heart. I. Ciin. Invest. 45: 40.

11. Olson, R. E. 1964. Abnormalities of myocardial metabolism. Circulation Res. 15 (Suppl. 2) : 109.

12. Sobel, B. E., J. F. Spann, Jr., P. E. Pool, E. H. Sonnenblick, and E. Braunwald. 1967. Normal oxidative phosphorylation in mitochondria from the failing heart. Circulation Res. 21: 355.

13. Gertler, M. M. 1959. Production of experimental congestive heart failure in the guinea pig. Proc. Soc. Exptl. Biol. 102 : 396.

14. Schwartz, A., and K. S. Lee. 1962. Study of heart mitochondria and glycolytic metabolism in experimentally induced cardiac failure. Circulation Res. 10: 321.

15. Gornall, A. G., C. J. Bardawill, and M. M. David. 1949. Determination of serum proteins by means of the biuret reaction. J. Biol. Chem. 177: 751.

16. Ceriotti, G. 1955. Determination of nucleic acids in animal tissues. J. Biol. Chem. 214: 59.

17. Webb, J. M., and H. B. Levy. 1955. A sensitive method for the determination of desoxyribonucleic acid in tissues and microorganisms. J. Biol. Chem. 213: 107.

18. Wittels, B., and R. Bressler. 1964. Biochemical lesion of diphtheria toxin in the heart. J. Clin. Invest. 43: 630.

19. Amenta, J. S. 1964. A rapid chemical method for quantification of lipids separated by thin-layer chromatography. J. Lipid Res. 5: 270.

20. Washko, M. E., and E. W. Rice. 1961. Determination of glucose by an improved enzymatic procedure. Clin. Chem. 7: 542 .

21. Bressler, R., and S. J. Friedberg. 1964. The effect of carnitine on the rate of palmitate incorporation into mitochondrial phospholipids. J. Biol. Chem. 239: 1364. 
22. Wittels, B., and R. Bressler. 1965. Two-dimensional thin-layer chromatographic isolation of fatty acyl carnitines. J. Lipid Res. 6: 313.

23. Bruno, G. A., and J: E. Christian. 1961. Correction for quenching associated with liquid scintillation counting. Anal. Chem. 33: 650.

24. Kornberg, A., and W. E. Pricer, Jr. 1953. Enzymatic synthesis of the coenzyme A derivatives of long chain fatty acids. J. Biol. Chem. 204: 329.

25. Fritz, I. B., and K. T. N. Yue. 1963. Long-chain carnitine acyl transferase and the role of acylcarnitine derivatives in the catalytic increase of fatty acid oxidation induced by carnitine. J. Lipid Res. 4: 279.

26. Pearson, D. J., and P. K. Tubbs. 1964. Tissue levels of acid insoluble carnitine in rat heart. Biochim. Biophys. Acta. 84: 772.

27. Marquis, N. R., and I. B. Fritz. 1964. Enzymological determination of free carnitine concentrations in rat tissues. J. Lipid Res. 5: 184.

28. Chase, J. F. A., D. J. Pearson, and P. K. Tubbs. 1965. The preparation of crystalline carnitine acetyltransferase. Biochim. Biophys. Acta. 96: 162.

29. Brendel, K., and R. Bressler. 1967. The resolution of (士)-carnitine and the synthesis of acylcarnitines. Biochim. Biophys. Acta. 137: 98.

30. Goldman, P., and P. R. Vagelos. 1961. The specificity of triglyceride synthesis from diglycerides in chicken adipose tissue. J. Biol. Chem. 236: 2620.

31. Stadtman, E. R. 1957. Preparation and assay of acyl coenzyme A and other thiol esters; use of hydroxylamine. In Methods in Enzymology. S. P. Colowick and N. D. Kaplan, editors. Academic Press, Inc., New York. 3: 931.

32. Dixon, W. J., and F. J. Massey, Jr. 1957. Introduction to Statistical Analyses. McGraw-Hill Book Company, New York. 2nd edition. 119.

33. Feinstein, M. B. 1962. Effects of experimental congestive heart failure, ouabin, and asphyxia on the high-energy phosphate and creatine content of the guinea pig heart. Circulation Res. 10: 333.

34. Fox, A. C., N. S. Wikler, and G. E. Reed. 1965. High energy phosphate compounds in the myocardium during experimental congestive heart failure. Purine and pyrimidine nucleotides, creatine, and creatine phosphate in normal and in failing hearts. J. Clin. Invest. 44: 202.

35. Wollenberger, A., and W. Schulze. 1961. Mitochondrial alterations in the myocardium of dogs with aortic stenosis. J. Biophys. Biochem. Cytol. 10: 285.

36. Pool, P. E., J. F. Spann, Jr., R. A. Buccino, E. H.
Sonnenblick, and E. Braunwald. 1967. Myocardial high energy phosphate stores in cardiac hypertrophy and heart failure. Circulation Res. 21: 365.

37. Bing, R. J., C. Wu, and S. Gudbjarnason. 1964. Mechanism of heart failure. Circulation Res. 15 (Suppl. 2) : 64 .

38. Bremer, J. 1962. Carnitine in intermediary metabolism. The metabolism of fatty acid esters of carnitine by mitochondria. J. Biol. Chem. 237: 3628.

39. Shepherd, D., D. W. Yates, and P. B. Garland. 1966. The rate-limiting step in the oxidation of palmitate or palmitoyl-coenzyme $\mathrm{A}$ by rat-liver mitochondria. Biochem. J. 98 : 3c.

40. Franekel, G., and S. Friedman. 1957. Carnitine. Vitamins and hormones; advances in research and applications. $15: 73$.

41. Gousios, A., J. M. Felts, and R. J. Havel. 1965. Effect of catecholamines, glucose, insulin, and changes of flow on the metabolism of free fatty acids by the myocardium. Metab. Clin. Exptl. 14: 826.

42. Chidsey, C. A., G. A. Kaiser, E. H. Sonnenblick, J. F. Spann, and E. Braunwald. 1964. Cardiac norepinephrine stores in experimental heart failure in the dog. J. Clin. Invest. 43: 2386.

43. Chidsey, C. A., E. Braunwald, and A. G. Morrow. 1965. Catecholamine excretion and cardiac stores of norepinephrine in congestive heart failure. $\mathrm{Am}$. J. Med. 39: 442.

44. Spann, J. F., Jr., C. A. Chidsey, P. E. Pool, and E. Braunwald. 1965. Mechanism of norepinephrine depletion in experimental heart failure produced by aortic constriction in the guinea pig. Circulation Res. 17: 321 .

45. Fritz, I. B. 1964. Carnitine effects on palmitate-1-C $C^{14}$ conversion to $\mathrm{CO}_{2}$ and glycerides by various tissue. Am. J. Physiol. 206: 1217.

46. Friedberg, S. J., and R. Bressler. 1965. The formation and isolation of long-chain acyl carnitines in mitochondria. Biochim. Biophys. Acta. 98: 335.

47. Wittels, B., and R. Bressler. 1965. Lipid metabolism in the newborn heart. J. Clin. Invest. 44: 1639.

48. Wittels, B., and R. Bressler. 1964. Lipid metabolism in the heart during fasting. Lab. Invest. 13: 794.

49. Bressler, R., and B. Wittels. 1966. The effect of thyroxine on lipid and carbohydrate metabolism in the heart. J. Clin. Invest. 45: 1326.

50. Norum, K. R. 1965. Activation of palmityl-CoA : carnitine palmityltransferase in livers from fasted, fat-fed, or diabetic rats. Biochim. Biophys. Acta. 98: 652. 